placed at the head of the list of candidates; and, if re-elected, shall take precedence of all others elected into the Council on the same day, and shall, with respect to each other, take precedence according to their former seniority on the Conncil.

13. That the examinations for the Fellowship shall be held twice in the year, at such times as the Council may appoint ; and that the Court of Examiners be authorized to hold special or extraordinary meetings for such examinations whenever the same may be found necessary.

14. 'That the Council shall have the power to elect to the Fellowship annually, without examination, under such conditions as they may establish by by-law, two members of the College of not less than twenty years' standing, on payment of the usual fee.

15. That all Fellows hereafter elected to the office of examiner shall go out of office at the end of five years from the time when he may have been elected, but the Council shall have the power of immediately re-electing him; and, if re-elected, he shall take precedence in the Court according to his former standing as a member thereof.

April 23, 1850.

By order of the Council)

EDMund BeLfodr, Secretary.

\section{SCOTTISH MEMORIAL TO SIR GEORGE GREY.}

Mr. SyMe presents his compliments to the Editor of The LANCET, and will feel obliged by his inserting the enclosed Memorial, which has been presented to Sir George Grey.

London, 27th April, 1850.

Unto the Right Honourable Sir George Grey, Bart, Principal Secretary of State for the Home Department of her Majesty's Government, the Memorial of the Royal College of Physicians of Edinburgh, the Royal College of Surgeons of Edinburgh, the Faculty of Physicians and Surgeons of Glasgow, and the Medical Faculty of the University of Edinburgh;

Humbly showeth, -

1. That in the year 1815, the Society of Apothecaries in London obtained an Act of Parliament which rendered it penal for any person to practise as an Apothecary in England without their licence.

2. That the legal definition of an apothecary's province is the dispensing of drugs for the treatment of internal diseases.

3. That the middle and lower classes of people in England are chiefly supplied with medical aid throngh the administration of drugs.

4. That the poor-laws of England preclude any person from being appointed to the medical charge of a Union who does not possess the apothecaries' licence.

5. That it is thus impossible, by any extent of education or examination in Scotland, to obtain the right of general practice in England.

6. That Scotland possesses various medical schools and licensing boards, which it is believed discharge their respective duties with at least not less efficiency than any other bodies of a similar kind in her Majesty's dominions.

7. That the medical education and licences of Scotland have long been regarded as affording the most ample qualification for admission into the Army and Navy, and other departments of the public service; and that many gentlemen possessing Scottish qualifications have attained the highest rank as physicians and surgeons in English practice.

8. That the existing restriction on general practice in England of gentlemen educated in Scotland is unjust, inconsistent with the Union between the two countries, and injurious to the interests of both, but especially the former, which is thus deprived of fully qualified medical practitioners, and forced to accept the services of those from whom a more limited education is required.

9. That your memorialists, the Royal College of Surgeons of Edinburgh, and the Faculty of Physicians and Surgeons of Glasgow, possessed certain exclusive privileges of practice, which they have voluntarily relipquished, so that there is now no restriction on medical practice in Scotland.

10. That in the event of its proving desirable for the arrangement of a general measure to establish uniformity of privilege on equality of qualification, your said memorialists, the Royal College of Surgeons of Edinburgh, and the Faculty of Physicians and Surgeons of Glasgow, together with the Royal College of Physicians of Edinburgh, are prepared to form a Conjoint Board of Examiners, and to regulate the edncation requisite for obtaining the licence of general practice in accordance with any system which may seem most expedient to a medical council, or other superintending authority over the medical profession.

11. That your memorialists, the Medical Faculty of the Uni- versity of Edinburgh, being engaged in teaching the various branches of medicine and surgery in the largest medical school of her Majesty's dominions, find their exertions im zeded by the regulations of the Society of Apothecaries in London, which interfere with preparatory study, by requiring the useless drudgery of a five years' apprenticeship, and enjoin the courses of medical study to be taken in an order different from that which, in the opinion of well-informed members of the profession, is nost advantageous for sound instruction.

12. That all of your memorialists, therefore, earnestly and respectfully pray that the unjust and injurious restriction of the Apothecaries' Act may be removed. And your memorialists will ever pray, \&c.,

President of the Royal College of Physicians of Edinburgh. JAMES SYME,

President of the Royal College of Surgeons of Edinburgh. James Watson,

President of the Faculty of Physicians and Surgeons of Glasgow. JoHn Hutton Balfour,

Dean of the Medical Faculty of the University of Edinburgh. Edinburgh, 22nd April, 1850.

\section{OXFORD MEMORIAL TO SIR GEORGE GREY.}

\section{Memorial to the Right Hon. Sir George Grey.}

SrR,-We, the undersigned members of the Royal College of Surgeons of England, resident in the University, city, and neighbourhood of Oxford, being informed that the Council of the said College have applied to her Majesty's Government for a modification of the Charter granted to them in the year 1843; and being of opinion that the said Council do not, in their proposed regulations, justly regard and consider the honour and interests of the members, whose college they represent; and being therefore dissatisfied with the "Resolutions" of the said Council, as announced in the month of February of the present year, respectfully but earnestly request, that any advice which you, Sir, as minister of the Crown, may think proper to offer on this matter, may be publicly declared and made known before the terms of the amended charter are confirmed, in order that the members may duly consider and express their opinion of its provisions.

With unfeigned respect for your high office and exalted character,

We are, Sir, your obedient servants, Joon, Oxford, diploma dated 1820 James Torry Hester, Oxford, 1821; John GodFReX, Oxford, 1822 ; JoHn Martin, Oxford, 1824 ; Thomas Allen, Oxford, 1830 ; Frederick Symonds, Oxford, 1837 ; EdwaRd R. Owen, Oxford, 1842; Rich a RD Fernandez FreErorn, Oxford, 1844 ; JohN M. Gunson, Oxford, 1848; Richard E. Rusher, Oxford, 1849; Henry Dixon, Watlington, 1843; Mainwaring Srurlock, Ensham, 1837 ; - Georae Coles, Woodstock, 1829 ; WiLliam Ley, Littlemore, 1831 ; J. S. BarReTT, Kingston, 1821; H. T. T. PaLmer, Woodstock, 1822 ; J. R. HoLMes, Kidlington, 1826 ; RrchaRD MaLraAr, Hooknorton, 1833 ; Edward Hyde, Witney, 1835 ; Wm. Wellington Hyde, Bloxham, 1839 ; Charles Holmes, Chipping Norton, 1838 ; J. B. StrepPARD, Kingston, 1849.

Oxford, April 29, 1850.

\section{PROVINCIAL MEDICAL AND SURGICAL ASSOCIATION.}

\section{Memorial presented to Sir George Grey, Bart., on Thursday, the 25 th ultimo.}

That your memorialists consist of the President and Council of the Provincial Medical and Surgical Association, which is a Society composed of physicians, surgeons, and general practitioners, principally resident in the provinces, amounting in number to nearly 2000 , and united together for the advancement of science, as well as the general well-being of the medical profession.

That your memorialists have taken special care to ascertain the sentiments of the whole body to which they belong, on the subject of Medical Reform, and for that purpose have caused meetings to be held of the Lancashire and Chrshire, the West Somerset, North Wales, Yorkshire, Bath and Bristol, Shropshire, South Eastern, and South Western branches, of which this Asso- 